June 1991

\title{
Effects of Transforming Growth Factor-Beta 1 (TGF-B1) on the Motility of Osteoblast-Like Cells
}

John Charles Griffiths

Follow this and additional works at: https://opencommons.uconn.edu/sodm_masters

\section{Recommended Citation}

Griffiths, John Charles, "Effects of Transforming Growth Factor-Beta 1 (TGF-B1) on the Motility of Osteoblast-Like Cells" (1991). SoDM Masters Theses. 46.

https://opencommons.uconn.edu/sodm_masters/46 


\title{
THE EFFECTS OF TRANSFORMING GROWTH FACTOR-BETA 1
}

(TGF- $\beta_{1}$ ) ON THE MOTILITY OF OSTEOBLAST-LIKE CELLS

\author{
John Charles Griffiths \\ B.S., Brigham Young University, 1984 \\ D.D.S., University of California at Los Angeles, 1988
}

\author{
A Thesis \\ Submitted in Partial Fulfillment of the \\ Requirements for the Degree of \\ Master of Dental Science \\ at
}

The University of Connecticut

1991 
Master of Dental Science Thesis

THE EFFECTS OF TRANSFORMING GROWTH FACTOR-BETA 1

(TGF- $\beta_{1}$ ) ON THE MOTILITY OF OSTEOBLAST-LIKE CELLS

Presented by

John Charles Griffiths, B.S., D.D.S.
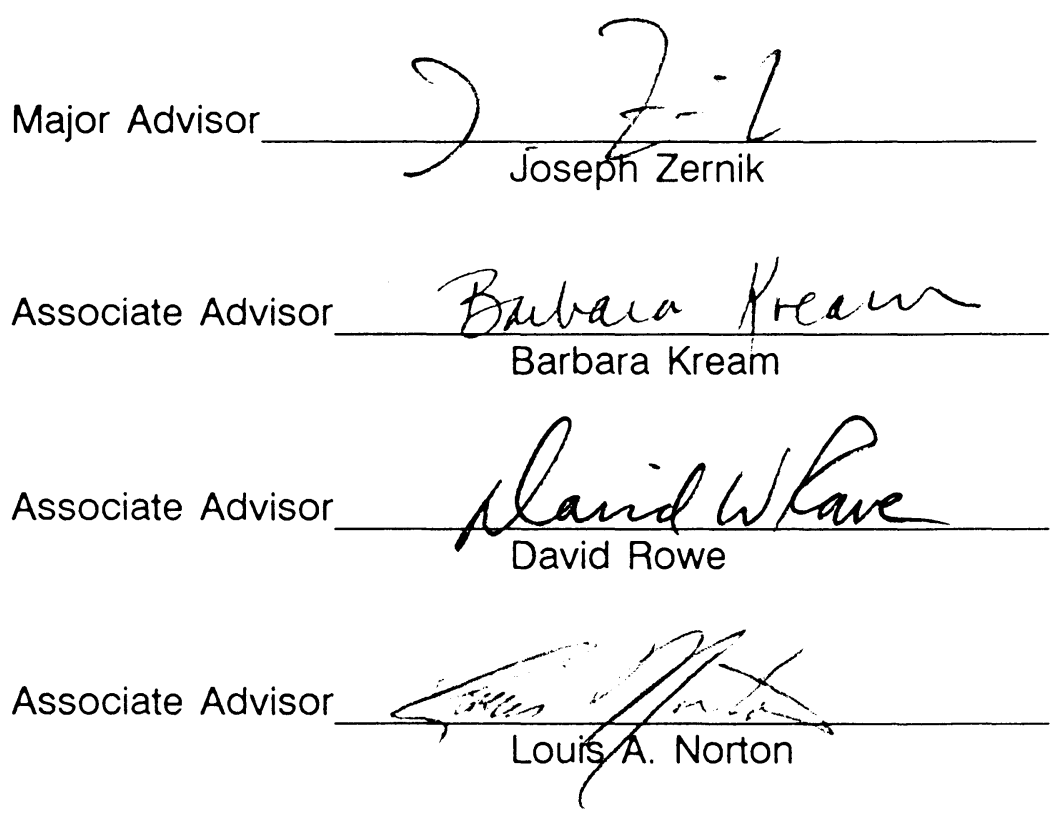

The University of Connecticut 


\section{DEDICATION}

I dedicate this work to my wife Laura as an acknowledgement of her support and as a symbol of our partnership in all that I have accomplished and may accomplish in the future. 


\section{ACKNOWLEDGEMENTS}

I wish to thank Dr. Joseph Zernik for his constant support and encouragement during the entire length of my thesis work and to the other members of my committee, Dr. Barbara Kream, Dr. David Rowe, and Dr. Louis Norton for their helpful comments and suggestions.

I also wish to express my appreciation to Kristine Tarwog for her help in the lab and to John Harrison for graciously providing MC3T3.E1 cells for this investigation.

Finally, I wish to acknowledge Dr. Spiro J. Chaconas and Dr. Angelo A. Caputo for introducing me to dental research. 


\section{TABLE OF CONTENTS}

PAGE

$\begin{array}{ll}\text { INTRODUCTION } & 1\end{array}$

BACKGROUND

Bone Growth and Development 3

Osteoblastic Phenotype 3

$\begin{array}{lr}\text { Transforming Growth Factor- } \beta & 8\end{array}$

$\begin{array}{lr}\text { Osteoblast-like Cell Motility } & 10\end{array}$

$\begin{array}{ll}\text { Neural Crest Cells } & 11\end{array}$

$\begin{array}{lr}\text { Fibroblast Locomotion } & 12\end{array}$

$\begin{array}{lc}\text { Cellular Adhesion } & 13\end{array}$

HYPOTHESIS AND SPECIFIC AIMS

METHODS AND MATERIALS 16

$\begin{array}{ll}\text { Cell Culture and Motility Assay } & 16\end{array}$

$\begin{array}{lr}{ }^{3} \mathrm{H} \text { Thymidine Incorporation Assay } & 17\end{array}$

$\begin{array}{ll}\text { Cell Growth Assay } & 17\end{array}$

$\begin{array}{lr}\text { Cell Adhesion Assay } & 18\end{array}$

$\begin{array}{lr}\text { RESULTS } & 19\end{array}$

DISCUSSION

Potential Mechanisms of Action of TGF- $\beta_{1}$ on the Motility of

$\begin{array}{ll}\text { Osteoblast-like Cells } & 26\end{array}$ 
SUMMARY AND CONCLUSIONS

TABLE AND FIGURES

REFERENCES 


\section{LIST OF TABLES}

PAGE

Table 1: ${ }^{3} \mathrm{H}$ Thymidine incorporation in MC3T3.E1 cells

\section{LIST OF FIGURES}

Figure 1: Wound healing assay using МС3T3.E1 cells

2: Reduction of MC3T3.E1 cell motility by TGF- $\beta_{1}$

3: $\quad$ Growth effects of TGF- $\beta$, on MC3T3.E1 cells

4: Motility of rat osteoblast-like and fibroblast-like cells

5: Growth of rat osteoblast-like and fibroblast-like cells

6: Motility of human osteoblast-like and fibroblast-like cells

7: $\quad$ Substrate adhesion of MC3T3.E1 cells

8: $\quad$ F-Actin staining of MC3T3.E1 cells using fluorescein

phalloidin

9: Morphology of control and treated MC3T3.E1 cells 


\section{INTRODUCTION}

Regulation of osteoblastic differentiation is a key element in the processes of bone development and fracture repair. One proposed regulator of osteoblastic differentiation is transforming growth factor-beta $1\left(\right.$ TGF- $\left.\beta_{1}\right)$ as has been shown both in cultured cells and in vivo. ${ }^{(1-3)}$ TGF- $\beta$, has been found to affect the proliferation, differentiation, and phenotypic expression of various connective tissue cells. ${ }^{(3-9)}$ In its latent form, TGF- $\beta_{1}$ exists as a high molecular weight complex. ${ }^{(10)}$ The acidic microenvironment created during bone resorption may regulate TGF- $\beta_{1}$ activity by converting it from a latent to an active form. ${ }^{(11,12)}$ In the active form, TGF- $\beta_{1}$ is a $\simeq 25,000$ dalton polypeptide. At least five closely related proteins of this family ,TGF$B_{1-5}$, have so far been identified and several of them may have important roles in regulating bone tissue activity. ${ }^{(5)}$ TGF- $\beta_{1}$ and TGF- $\beta_{2}$ have been the most extensively studied, and the two are interchangeable in most biological assays. ${ }^{(3,13,14)}$ Both are produced by various cells (including osteoblasts) and are very abundant in bone. ${ }^{(1,11,15)}$ Both are also known to have both inhibitory and stimulatory effects on the proliferation of fetal rat calvarial cells $s^{(18)}$, rat osteosarcoma cells ${ }^{(30)}$, and mouse calvarial-derived MC3T3.E1 cells. ${ }^{(4,6,9,13,17)}$ In vivo studies of fracture repair demonstrated increased rates of proliferation following TGF- $\beta_{1}$ or TGF- $\beta_{2}$ treatment. In addition, TGF- $\beta_{1}$ and TGF- $\beta_{2}$ have been shown to be regulators of extracellular matrix protein ${ }^{(7,18,19)}$ and alkaline phosphatase expression by various connective tissue cells. $^{(4,9,13,17)}$ In vivo studies have shown that both factors are capable of initiating a repair process and callus formation in uninjured bone. ${ }^{(20)}$ TGF- $\beta_{1}$ and TGF- $\beta_{2}$ have 
also been shown to be chemotactic agents for both fetal rat calvariae and osteoblast-like osteosarcoma cells. ${ }^{(12)}$ The purpose of this study is to characterize cell motility of various osteoblast-like and fibroblast-like cells, using the wound healing assay, to investigate the effects of TGF- $\beta_{1}$ on the motility of osteoblast-like MC3T3.E1 cells, and to explore potential cellular and molecular underlying mechanisms.

We demonstrate that osteoblast-like cells, ROS $17 / 2.8$ and SAOS-2, have significantly lower motility rates than fibroblast-like EL2 and HT cells. While untreated osteoblastlike МС3T3.E1 cells exhibit motility rates similar to the fibroblast-like cell lines, TGF- $\beta_{1}$ decreases the motility of MC3T3.E1 cells, and its proliferative effects on the growth of the cells is delayed. This TGF- $\beta_{1}$ mediated decrease in cell motility is not accompanied by a change in MC3T3.E1 adhesion to fibronectin or vitronectin. 


\section{BACKGROUND}

\section{Bone Growth and Development}

Although one bone appears no different from another at the histological level, bone growth is generally classified as endochondral, intramembranous, or suturai. Endochondral bone formation, which occurs among other places at the head of the mandibular condyle as well as the base of the skull, takes place upon a cartilaginous matrix model, with the cartilage immediately preceding the bone in development. In intramembranous bone formation, which begins embryonically at multiple sites within each bone of the cranial vault, the maxilla, and the body of the mandible, bone develops within a soft connective tissue membrane rather that on a cartilaginous model. Sutural bone growth occurs exclusively in the skull and involves the deposition of bone at two locations simultaneously on either side of the suture.

\section{Osteoblastic Phenotype}

Traditionally, differentiated cells such as osteoblasts have been identified by their location in tissues. However, in recent decades as a result of investigations into the relationship between genes and proteins, differentiation came to be defined as a change in the proteins synthesized by the cell. Some of these proteins are 
secreted, allowing cells to determine the shape and composition of their environments. Conversely, the environment produces signals received by the cell, influencing its phenotypic expression. ${ }^{(21)}$ Differentiation, then, can be viewed as a dynamic interaction in which neighboring cells participate collectively to determine the structure and function of a tissue. With this idea of differentiation in mind, the expression of the osteoblastic phenotype can be seen as a continuum along which cells ranging from less differentiated pre-osteoblasts to more differentiated mature osteoblasts and osteocytes may be found. (22)

The osteoblast is a mononucleated cell that synthesizes both collagenous and noncollagenous bone proteins, which are deposited as osteoid, and is responsible for the mineralization of the osteoid. The osteoblast is believed to be derived from a multipotent mesenchymal cell or alternatively from a perivascular cell and is generally believed to differentiate through a precursor cell or pre-osteoblast. In vivo, osteoblasts or lining cells are found as a cellular layer covering most of the bony surface. When the osteoblasts are actively synthesizing bone matrix, they appear as plump cells with open-faced nuclei and abundant basophilic cytoplasm. ${ }^{(23)}$ When the cells are inactive, they are more squamous in appearance, have close-faced nuclei and are termed lining cells.

As osteoblasts secrete their matrix, some of the cells become entrapped and are then called osteocytes. The number of osteoblasts that become osteocytes can vary 
and is dependent upon the rate of bone formation. After their formation, osteocytes lose most of their matrix forming ability and become reduced in size. These entrapped osteocytes maintain communication with other osteocytes and with osteoblasts through enclosed channels or canaliculi. It is this osteocyte-osteoblast complex which must remain intact if the bone is to remain vital.

One of the hallmarks of cellular differentiation is the synthesis of phenotype-specific macromolecules; in osteoblasts these include alkaline phosphatase, osteocalcin, and type I collagen. ${ }^{(22)}$ Alkaline phosphatase, an enzyme essential to the process of mineralization, has long been recognized as an osteoblastic marker. Alkaline phosphatase is found in abundance in osteoblastic cells, as well as in cartilage cells prior to calcification. Alkaline phosphatase is also found in other cells and is relatively abundant in cells of the liver, kidney, intestine, and placenta.

In addition to alkaline phosphatase, several other potential markers of the osteoblastic phenotype have been identified. For example, the presence of collagen type I, the major constituent of the bony matrix, can be demonstrated immunohistologically in newly synthesized osteoid. ${ }^{(24)}$ Type I collagen has also been shown to be synthesized in bone explants in culture, and celis isolated from calvaria have been observed to preferentially produce type I collagen. ${ }^{(56)}$ Osteoblasts in bone almost exclusively synthesize type I collagen ${ }^{(59)}$ and probably produce very little or no type III collagen. 
Bone also contains non-collagenous proteins, the most abundant of which is Bone Gla Protein (BGP) or osteocalcin. ${ }^{(25)}$ Osteocalcin is a small protein produced by bone explants and osteoblast-like cell lines. Its synthesis and secretion have thus far been exclusively described in bone forming cells and can, therefore, also be considered a marker of the osteoblastic phenotype.

Certain hormones including parathyroid hormone (PTH), vitamin D, and glucocorticoids have been shown to effect bone growth and mineralization. These tissue-specific hormone-responses are also considered markers of osteoblastic cells. The effects of PTH on osteoblastic cells has been the subject of a number of investigations. Rao, et al. ${ }^{(28)}$ investigated the effects of PTH on cultures of calvarial derived bone cells which resulted in increased levels of CAMP within the cells. Rodan and Rodan ${ }^{(22)}$ noted similar results using freshly isolated calvarial cells and suggested that the PTH may affect the cytoskeleton, synthesis of alkaline phosphatase and collagen, and growth of osteoblastic cells. These authors also reviewed the evidence that osteoblasts possess receptors for $1,25(\mathrm{OH})_{2}$ vitamin $D_{3}$. In addition, glucocorticoids have been shown to be involved in bone cell regulation principally by inhibiting the growth of the cells. ${ }^{(27)}$

Due to the problems and complexities inherent in trying to study osteoblastic cells in vivo or with establishing homogenous primary osteoblastic cell cultures, numerous cell lines exhibiting osteoblast-like cell characteristics have been isolated and 
cultured for use in vitro. Some of these cell lines are ROS $17 / 2.8,{ }^{(30)}$ derived from a rat osteosarcoma, MC3T3.E1, ${ }^{(28)}$ an immortalized clonal murine calvaria-derived cell line, and SAOS-2, ${ }^{(29)}$ derived from a human osteosarcoma. Majeska and Rodan ${ }^{(30)}$, for example, cloned and selected ROS 17/2.8 on the basis of its osteoblastic characteristics, namely - high level of alkaline phosphatase expression, responsiveness to PTH and $1,25(\mathrm{OH})_{2}$ vitamin $D_{3}$, and formation of mineralized tissue in vivo. Along the same line, Sudo, et al. ${ }^{(28)}$ demonstrated the osteoblastic nature of the MC3T3.E1 cell line on the basis of its high alkaline phosphatase activity in the quiesient state and its ability to form hydroxyapatite mineralized matrix in culture. Osteoblast-like cell lines have also been shown to exhibit osteoblastic characteristics in terms of collagen type I production. For example, the alkaline phosphatase rich osteoblast-like cell line ROS $17 / 2.8$ was found to synthesize approximately $98 \%$ collagen type I whereas a more fibroblastic-like cell isolated from the same tumor, ROS $25 / 1$, produced $70 \%$ type I collagen and $30 \%$ type III collagen. ${ }^{(31)}$

Using osteosarcoma cell lines,investigators have demonstrated a close correlation between biologic responses to $1,25(\mathrm{OH})_{2}$ vitamin $D_{3}$ and certain osteoblastic properties such as elevated alkaline phosphatase and the formation of bone in subcutaneous tissues. ${ }^{(22)}$ However, these effects at times were varied and may have depended on the level of differentiation or maturation of the cells. 
Transforming Growth Factor-B

Transforming growth factors-в (TGF-в) are a family of polypeptides with a Mr of $\simeq 25,000$ daltons. So far at least 5 forms of the growth factor, named TGF-B ${ }_{1-5}$, have been identified, and the biochemistry and molecular biology of the first two factors, TGF- $\beta_{1}$ and TGF- $\beta_{2}$, have been studied and described in detail. ${ }^{(2)}$ The existence of multiple forms of TGF- $\beta$ was not well defined when much of the earlier work with the growth factor was done. Therefore, the term TGF- $\beta$ will refer to either TGF- $\beta_{1}$ or TGF- $\beta_{2}$ unless otherwise indicated. TGF- $\beta$ stimulates anchorage independent growth and modulates the growth and differentiation of various cell types. $^{(4)}$ TGF- $\beta$ has been isolated from platelets, kidney, and placenta, is very abundant in bone, and is known to be synthesized by osteoblasts. Furthermore, Seyedin, et al. ${ }^{(15)}$ demonstrated that Cartilage Inducing Factor A (CIF-A), which was isolated from bovine demineralized bone, was in fact identical in structure to TGF$B_{1}$. Although the mechanism of action of $\mathrm{TGF}_{-B_{1,2}}$ on the various tissues remains unknown, current research indicates that TGF- $\beta_{1,2}$ may be the prototypes of a family of homologous polypeptides that regulate the control and development of tissues and organisms. ${ }^{(33)}$

Rosen, et al. ${ }^{(5)}$ found that TGF-B inhibits phenotypic expression of osteoblasts and chondroblasts and suggest that this activity may be mediated through interactions between the extracellular matrix and the cytoskeletal elements. Wrana, et al. ${ }^{(18)}$, 
examining rat calvarial bone cell populations, found that TGF-B increased the synthesis of secreted proteins including collagen, fibronectin, and plasminogen activator inhibitor.

The effects of TGF $_{-B_{1,2}}$ on connective tissue cells are varied and have been the subject of a number of investigations. Noda and Rodan, ${ }^{(4)}$ reported that TGF- $\beta_{1}$ causes changes in shape, inhibits growth and suppresses alkaline phosphatase expression in MC3T3.E1 cells. The authors further concluded that the growth factor is abundant in bone and also promotes the differentiation of muscle derived fibroblastic cells into cartilage. ${ }^{(34)}$ Uneno, et al. ${ }^{(6)}$ studied the effects of TGF-B on the MC3T3.E1 cell line and found them to be biphasic. Initially, TGF- $\beta_{1}$ caused an increase in cellular differentiation to the osteoblastic phenotype with decreased proliferation of the MC3T3.E1 cells, but chronic exposure actually stimulated cellular proliferation and inhibited osteoblastic phenotype expression. Centrella, et al. ${ }^{(35)}$ further suggest that TGF- $\beta$ probably plays a role in early bone and cartilage development and that it tends to increase or decrease the number and activity of certain cell populations at various stages of development.

As evidenced by these somewhat contradictory effects of TGF- - $_{1,2}$, it is likely that the mechanism of action of these growth factors is complex and is dependent upon cell type, cell surface receptors, duration of exposure to the cell, and interaction with other intracellular and extracellular components which may function to regulate the 
effects of TGF- $B_{1}$ and TGF- $\beta_{2}$.

Mundy and others ${ }^{(60,32)}$ have suggested that TGF- $\beta$ may be involved in the coupling mechanism of bone formation and bone resorption which occurs during bone remodeling. TGF- $\beta$ is present in bone as a latent complex, and as resorption occurs on the surface of the bone, this osteoclastic activity is proposed to have a role in releasing active TGF- $\beta$ from its latent form. This active TGF- $\beta$ is now available to exert is biological effects which may include the inhibition of further osteoclast activity and replication of osteoblast precursors, followed by differentiation of the precursor cells, which involves secretion of matrix proteins and mineralization of bone. ${ }^{(00)}$

\section{Osteoblast-like Cell Motility}

During embryonic development, pre-osteoblasts or mesenchymal cells migrate at specific times to specific locations within the developing embryo. Later as bones are formed or as bone repair occurs, the pre-osteoblasts are triggered to differentiate and move to where the bone is formed. This bone remodeling has also been suggested to require local coordination of osteoblast and osteoclast position, a concept previously described as one of the basic tenants in a hypothesis developed by Rodan and Martin ${ }^{(81)}$ to explain the increase in bone resorption caused by dexamethasone. According to this hypothesis, dexamethasone induces bone resorption, at least in part, by causing the osteoblasts lining the bony surface to 
move which, in turn, results in areas where the bony surface is exposed. Osteoclasts then respond by adhering to these exposed areas, and bone resorption occurs. Therefore, a key element in the process of bone remodeling may be the regulation of cell movement.

Although extensive research and a great deal of literature has been devoted to studies of embryonic cell movement, behavior, and migration, the subject of osteoblast migration, at least in terms of quantifying the migration, has been somewhat over-looked. However, in order to help understand the mechanisms and factors involved in osteoblastic cell motility, information concerning the migration and movement of other cell types should be considered to form a basis for the study of bone cells.

\section{Neural Crest Cells}

One area that has been studied extensively is that of neural crest cell migration during embryogenesis. In order to migrate, neural crest cells require a specific type of substrate and a space in which to move..$^{(36)}$ As observed in scanning electron microscopy, neural crest cells send out filopodia for use in cell translocation which then adhere to the substrate in the extracellular matrix (ECM). The composition of the ECM has been well-documented in the literature. Glycosaminoglycans were among the first ECM substrates to be identified. The most abundant of the ECM 
proteins at the time of neural crest migration is hyaluronic acid, which both enlarges the space and provides a substratum for cell progression. The subsequent decrease in hyaluronic acid concentration has been correlated with a reduction in cell motility and with cellular aggregation. ${ }^{(37,38)}$ in addition to the amorphous material in the migratory substrate, abundant fibrillar material is also found consisting mostly of fibronectin and lesser amounts of types I and III collagen. Fibronectin, a large glycoprotein, has been proposed to play an important role in several cellular phenomena such as migration and adhesion and has been shown to have specific binding properties to a cell surface receptor, to collagen, and to glycosaminoglycans. ${ }^{(39,40)}$ In the migration process, fibronectin fibers are believed to play a role as anchorage sites for the filopodia sent out by neural crest cells, a view supported by Rovasio, et al. ${ }^{(41)}$

\section{Fibroblast Locomotion}

Fibroblasts are another cell type which has been studied in depth in terms of cell movement and behavior. The fibroblast is a connective tissue cell of mesodermal origin which has the capacity to both degrade and synthesize fibrillar collagen and the other components of the interstitial connective tissue matrix. Fibroblasts move as individual cells and do not form permanent junctions one with another. ${ }^{(4)}$ Here, the author suggests that the migrational ability of the fibroblast is related to the development of internal fibers or microfilament bundles composed of actin and 
myosin. Rapidly moving fibroblasts in the early migrational stage do not have conspicuous stress tibers whereas slowly moving or stationary fibroblasts have well developed stress fibers. These stress fibers are believed to be involved with substrate adhesion, the duration of which may be directly related to the rate of cell movement. The increased duration of the adhesions when fibroblast movement slows down may be associated with an increased production of fibronectin by the cell, which is known to occur, or it might be regulated intracellularly by some environmental signal.

\section{Cellular Adhesion}

Studies have shown that certain proteins, identified as constituents of the extracellular matrix, enhance the attachment or surface adhesion of cells. The presence of these proteins in the ECM is significant because understanding how cells attach to the substrate and spread may lead to an increased understanding of cellular differentiation and migration. One of these ECM proteins, fibronectin, is a well-characterized extracellular glycoprotein which interacts strongly with other extracellular matrix molecules and which causes the attachment and spreading of most cells when it is presented to them as an insoluble substrate. ${ }^{(42)}$

The evidence that fibronectin has an affinity for many types of cells is provided by the observation that cells in solution attach preferentially to surfaces coated with the 
protein and that the adhesion of cells to collagen matrices is mediated by fibronectin. ${ }^{(43)}$ The mechanisms of cellular adhesion to fibronectin and other extracellular matrix proteins is the subject of a number of current investigations. Much of this research has centered around a family of cell surface receptors called integrins. ${ }^{(5 n}$ Integrins are heterodimeric proteins which span the cell membrane, connecting the extracellular matrix to the cytoskeleton of the cell. ${ }^{(44)}$ Several members of the integrin family have demonstrated a special affinity for extracellular matrix proteins containing the tripeptide arginine-glycine-aspartate (RGD) sequence, as their cell recognition site. Proteins containing the RGD sequence include fibronectin, vitronectin, collagen, and osteopontin. ${ }^{(44)}$ Decreased motility of osteoblasts, then, could be related to an increased number of cell surface receptors on the osteoblasts and therefore increased adhesion of the cells to the extracellular matrix. 


\section{HYPOTHESIS AND SPECIFIC AIMS}

TGF- $\beta$, has been suggested as a potential factor in coupling bone formation and resorption during bone remodeling, which requires local changes in osteoblastic cell position. Thus, TGF- $\beta$, may regulate osteoblast-like cell motility.

The specific aims of this thesis proposal are as follows:

1. Adapt an assay for cell motility of osteoblast-like (MC3T3.E1, ROS 17/2.8, SAOS-2) and fibroblast-like (EL2 and HT) cells.

2. Determine the effects of TGF- $\beta_{1}$ on the growth and motility of MC3T3.E1 cells.

3. Perform cell adhesion assays to determine the effects of TGF- $\beta_{1}$ on the attachment of MC3T3.E1 cells to various natural and synthetic proteins such as fibronectin, vitronectin, type I collagen, albumin, and Peptite 2000.

4. Propose a mechanism for the effect of TGF- $B$ on osteoblast-like cell motility. 


\section{METHODS AND MATERIALS}

\section{Cell Culture and Motility Assay}

Cells of the mouse calvarial osteoblastic cell line MC3T3.E1 $1^{(28)}$ were routinely maintained and cultured in F-12 medium containing $10 \%$ fetal calf serum (FCS) on $100 \mathrm{~mm}$ tissue culture plates (Falcon Laboratories). For the motility assay, cells were plated in F-12 medium containing $2 \%$ FCS on $16 \mathrm{~mm}$ wells, crossmarked on their inferior surfaces, at a density of $2 \times 10^{4} \mathrm{cells} / \mathrm{cm}^{2}$. Six hours after plating, cells were fed with either F-12 supplemented with $2 \%$ FCS or F-12 supplemented with $2 \%$ FCS and 2ng/ml TGF- $\beta_{1}$ (from porcine platelets, R \& D Systems, Minneapolis, MN). After 24 hours, a linear wound was placed across the center of each well using a rubber policeman, resulting in a cell-free area or streak of about $5 \mathrm{~mm}$ in width. Cell cultures were maintained for 10-12 days and were fed every 3-4 days with either the test or control medium. Cell movement from the position of the original streak border, or growth front, into the clear area was determined by superimposing photomicrographs taken at various time points using the crossmarks. The growth front was defined at each time point as a straight line parallel to the streak with only 10 cells on the streak side over a $0.5 \mathrm{~mm}$ wide length of the streak border. In order to quantitate these differences we followed the change in growth front migration over the time of the experiment. 
To compare the motility characteristics of osteoblast-like and fibroblast-like cells, this assay was also performed using ROS $17 / 2.8^{(30)}$ and SAOS-2 ${ }^{(29)}$ osteoblast-like cells and $E L 2^{(45)}$, and $H T^{(48)}$ fibroblast-like cells.

\section{H Thymidine Incorporation Assay}

MC3T3.E1 cells were plated on tissue culture 2-chamber slides (Nunc, Inc., Naperville, II) at $2 \times 10^{4}$ cells $/ \mathrm{cm}^{2}$ and wounded as described in the cell motility assay. ${ }^{3} \mathrm{H}$-Thymidine $(0.1 \mathrm{uCi} / \mathrm{mL})$ was added at the time of wounding in both treated and control wells. The medium containing the ${ }^{3} \mathrm{H}-$ Thymidine was removed from the wells 12-14 hours later and both treated and control cells were fixed and autoradiographed for 7 days in N-3 emulsion (Kodak, Rochester,NY). Consequently, the slides were developed, fixed, and stained for 6 minutes with $0.1 \%$ crystal violet. The proportion of labeled vs. non-labeled cells at the streak border of each slide was then determined using photomicrography. The experiment was repeated on separate wells 3 days following placement of the wound. Quadruplicate wells were used for each experimental time point.

\section{Cell Growth Assay}

MC3T3.E1 cells were cultured in $\mathbf{2 4}$ well plates (Falcon laboratories) at a density of $4 \times 10^{4}$ cells $/ \mathrm{cm}^{2}$. Following overnight incubation with medium containing $10 \%$ 
serum, the medium was replaced with either fresh medium or medium with $2 \mathrm{ng} / \mathrm{mL}$ TGF- $\beta_{1}$. TGF- $\beta_{1}$ treated and control cells were counted at various time points, in triplicate, using a Coulter Counter (Coulter Electronics Inc., Florida) following dissociation by treatment with $0.25 \%$ trypsin-EDTA in PBS at $37^{\circ}$.

To evaluate the growth rates of osteoblast-like and fibroblast-like cells, this assay was repeated using untreated ROS 17/2.8 and EL2 cells.

\section{Cell Adhesion Assay}

Non-tissue culture 100mm plates (WWR Scientific Inc., San Francisco, CA) were coated with vitronectin, fibronectin, type I collagen (Telios Pharmaceuticals, San Diego, CA), Peptite 2000 (a synthetic oligopeptide that supports cell adhesion, Telios) and albumin (Promega). Solutions of each protein diluted in sterile PBS were prepared at concentrations of $0,0.15,0.5,1.5,5.0$, and $25 \mathrm{ug} / \mathrm{ml}$. Substrate solutions (five-30ul droplets at each concentration) were plated on culture dishes and allowed to dry at room temperature for a minimum of 24 hours. Cells preincubated for 24 hours with $2 \mathrm{ng} / \mathrm{ml} \mathrm{TGF-} \beta_{1}$ and control cells were then placed on the coated plates at $2 \times 10^{4}$ cells $/ \mathrm{cm}^{2}$. Following a 90 minute incubation at $37^{\circ} \mathrm{C}$, the medium containing non-attached cells was removed, and the number of attached cells within a $0.1 \mathrm{~mm}^{2}$ area over each droplet was counted. A minimum of eight samples for each peptide at each concentration were evaluated in these experiments. 


\section{RESULTS}

Figure 1 shows the results of a representative assay, where the initial position of the streak border at the time of wounding in control and treated wells (Fig. 1a and 1c, respectively) is compared to the position of the growth front in the corresponding plates 11 days later (Fig.1b and Fig.1d, respectively). Cells in control wells (Fig. 1b) have migrated to near confluence into the streak area. Cells on the right side of Fig. 1b have migrated from the opposite side of the streak. However, in wells treated with TGF- $\beta_{1}$ (Fig. 1d), a large portion of the cell free area remains intact 11 days after the placement of the wound, and the growth front has migrated only about $1.0 \mathrm{~mm}$ from the original position of the streak border. Treatment of MC3T3.E1 cells with TGF- $\beta_{1}(2 \mathrm{ng} / \mathrm{ml})$ resulted in a significant decrease in growth front migration into the cell-free area of the wounded well (Fig. 2). Treated cells exhibited a 3-fold reduction in motility $(0.06 \pm 0.004 \mathrm{~mm} /$ day $)$ compared to control cells $(0.22 \pm 0.07 \mathrm{~mm} /$ day $)$.

The results of the cell growth assay indicate that TGF- $\beta$, has a delayed proliferative effect of MC3T3.E1 cells (Fig. 3). Twenty-four hours after plating, both treated and control cells exhibited a $70 \%$ decrease in cell number, probably due to cell death or to cells not adhering to the culture dish. Up to day 3, cells treated with TGF- $\beta_{1}$ showed a 3-fold decrease in growth rate compared to non-treated cells. However, by day 7, TGF- $\beta_{1}$ treated cells demonstrated a near 2 -fold increase in growth rate 
compared to control cells.

The rate of cell front migration (Fig. 4) for EL2 (rat fibroblast-like cells) was $0.29 \pm 0.03 \mathrm{~mm} /$ day compared to $0.07 \pm 0.01 \mathrm{~mm} /$ day for ROS $17 / 2.8$ (rat osteoblastlike cells), although growth rates of the two cell lines are similar (Fig. 5). SAOS-2 (Human osteosarcoma osteoblast-like cells) demonstrated an even slower rate of cell motility (Fig. 6), $0.046 \pm 0.007 \mathrm{~mm} /$ day, compared to a rate of $0.47 \pm 0.06 \mathrm{~mm} /$ day for HT (human fibroblastic cells).

In order to better understand the role of cell proliferation in MCЗT3.E1 wound healing, we labeled dividing cells with ${ }^{3} \mathrm{H}$-thymidine. Following a 12 hour incubation period with ${ }^{3} \mathrm{H}$-thymidine added at the time of wounding, wells treated with TGF- $\beta_{1}$ showed an increased percentage of labeled cells at the streak border compared to control wells $(38.0 \pm 7.0$ and $25.0 \pm .05$ respectively, $p \leq 0.01$ ) (Table 1). After an eighteen hour labeling period 3 days later, there was a similar percentage of labeled cells at the streak border in wells treated with TGF- $\beta_{1}(73.0 \pm 9.0)$ compared to control wells (70.0 \pm 9.0, not significant). The student's t-test was used for statistical analysis of the results of this assay.

In order to investigate the role of cell-matrix interactions in the observed changes in cell motility, we carried out cell adhesion assays. ${ }^{(43)}$ Peptite-2000 allowed the highest level of attachment of cells ( 170 cells $/ 0.1 \mathrm{~mm}^{2}$ in treated cells and 175 cells $/ 0.1 \mathrm{~mm}^{2}$ 
in control wells) with $1 / 2$ maximal attachment at $2.5 \mathrm{ug} / \mathrm{ml}$ in each instance. Fibronectin exhibited the next highest level of attachment $\left(100\right.$ cells $/ 0.1 \mathrm{~mm}^{2}$ in treated samples and 90 cells $/ 0.1 \mathrm{~mm}^{2}$ with non-treated cells) with $1 / 2$ maximal attachment to fibronectin occuring at protein concentrations of $4.7 \mathrm{ug} / \mathrm{ml}$ and 3.0 $\mathrm{ug} / \mathrm{ml}$ for treated and non-treated cells respectively. Adhesion assays using vitronectin as substrate failed to plateau at $25 \mathrm{ug} / \mathrm{ml}$ and therefore, $1 / 2$ maximal values could not be determined. Additionally, MC3T3.E1 cells did not adhere to type I collagen or albumin at any of the assayed protein concentrations since the number of attached cells was no different than background levels (areas of the plate where no substrate was present). However, no significant differences were found when comparing numbers of attached cells between treated and non-treated samples for any of the proteins used.

To evaluate possible effects of TGF- $\beta_{1}$ on the cytoskeletal structure of MC3T3.E1 cells, which could in turn effect the migratory ability of the cells, we stained the cells for F-actin microfilaments, a principle component of the cytoskeleton. MC3T3.E1 cells incubated for 72 hours with TGF- $\beta_{1}(2 \mathrm{ng} / \mathrm{ml})$ were stained for 20 minutes with a $5 \%$ solution of fluorescein phalloidin (Molecular Probes, Eugene, OR; 3.3 micromolar). Fluoroscopic examination of the stained cells revealed a prominent cytoskeletal arrangement, but no differences could be found in the cystoskeletal organization between TGF- $\beta_{1}$ treated and control MC3T3.E1 cells (Fig. 8). 


\section{DISCUSSION}

We have chosen to use the MC3T3.E1 cell line to test the effects of TGF- $\beta_{1}$, on osteoblast-like cell motility since these cells have previously been shown to exhibit many of the characteristics of the osteoblastic phenotype including high alkaline phosphatase activity in the confluent state, and the ability to differentiate and mineralize in vitro. ${ }^{(28,48)}$ Moreover, it has previously been shown that TGF- $\beta_{1}$ at $2 \mathrm{ng} / \mathrm{ml}$ induces alkaline phosphatase activity and cell-shape changes in these cells. ${ }^{(10)}$

Our findings that TGF- $\beta_{1}$ stimulates the proliferation of MC3T3.E1 cells correlates with the findings of other investigators. Vakicevic, et al. ${ }^{(17)}$ found that TGF- $\beta,(2.5 \mathrm{ng} / \mathrm{mL})$ inhibited MC3T3.E1 proliferation up to 24 hours but then stimulated proliferation after 48 hours. Uneno, et al. ${ }^{(6)}$ also demonstrated a similar effect on the proliferation of MC3T3.E1 cells treated with TGF-B; a decrease in proliferation was observed up to 40 hours of treatment followed by increased cell growth after longer treatment time. Jennings, et al. ${ }^{(14)}$ reported that both TGF- $\beta_{1}$ and TGF- $\beta_{1}$, were mitogenic for chicken embryonic calvarial bone cells. Centrella, et al. ${ }^{(16)}$ have also shown that TGF- $\beta$ stimulates replication in fetal-rat calvarial cells, but that the effect is biphasic and depends on the concentration of TGF- $\beta$ and on cell density. Using ${ }^{3} \mathrm{H}$ thymidine incorporation, Joyce, et al. ${ }^{(20)}$ demonstrated that TGF- $\beta(10 \mathrm{ng} / \mathrm{mL})$ triggered a 2-fold increase in cell proliferation in fracture callus organ culture, largely comprising connective tissue cell types. These investigators also showed that TGF- $\beta$ can 
stimulate intramembranous bone formation during fracture repair. Northern blot analyses demonstrated peak levels of TGF- $\beta$ in the hard callus 5 days after fracture indicating that TGF- $\beta$ has a continuing role in regulating bone formation.

Alternatively, some investigators have reported that TGF- $\beta$ has an inhibitory effect on osteoblast-like cell proliferation. Noda and Rodan ${ }^{(4)}$ reported the growth of MС3Т3.E1 cells was decreased by up to $40 \%$ following treatment with $2 n g / m L$ TGFB. Elford, et al. ${ }^{(8)}$ also reported a significant decrease in the growth of MC3T3.E1 cells treated with $1 \mathrm{ng} / \mathrm{mL}$ TGF- $\beta$. Finally, Ibbotson, et al. ${ }^{(13)}$ found that TGF- $\beta$ had no effect on cell proliferation of MC3T3.E1 cells as measured by DNA content. The authors further concluded that changes in cell proliferation do not play a role in any of the actions of TGF- $\beta$.

The varied and at times even contradictory effects of TGF- $\beta$ on proliferation of osteoblastic cells are probably due to differences in experimental conditions, serum type and concentration, concentration of TGF- $\beta$, and measurement techniques. These results, then, indicate that the effects of TGF- $\beta$ on the growth of osteoblastlike cells are complex and involve numerous factors as well. ${ }^{(8)}$ Otherwise, these differences may be related to changes in MC3T3.E1 cells which have been maintained for long time periods in different laboratories. 
In addition to the wound healing assay using a monolayer culture utilized in this investigation, other techniques have been used to evaluate cell motility. Davies, et al. ${ }^{(49)}$ used charged resin beads as a substrate for migration of osteoblasts from rat parietal bones, showing that the morphology of the cells is affected by the charge on the beads. Pfeilschifter, et al. ${ }^{(12)}$ used blind-well chemotaxis chambers to evaluate the chemotactic response of osteoblast-like cells to TGF- $\beta_{1}$ and TGF- $\beta_{2}$. These authors showed maximal chemotaxis in cells treated with $5-15 \mathrm{pg} / \mathrm{ml}$ of TGF- $\beta_{1}$ and TGF- $\beta_{2}$, while 48 hour preincubation of the cells with concentrations above $100 \mathrm{pg} / \mathrm{ml}$ of both growth factors abolished the chemotactic response. A more common technique used in studying cell motility is a Boyden-type chamber containing gelatincoated polycarbonate filters. ${ }^{(50,51)}$ Though other techniques are available, we chose the culture plate wound healing assay due to its simplicity of design and our initial observation that MC3T3.E1 cells plated on tissue culture plastic differ in their morphology when treated with TGF- $\beta_{1}$ (Fig. 9), a finding previously reported by Noda and Rodan. ${ }^{(4)}$

Our findings that osteoblast-like cells exhibit reduced cell motility compared to fibroblast-like cells is interesting in that it suggests that a decreased ability of the cells to move may be characteristic of osteoblastic differentiation. Based on previous studies, pre-osteoblast undifferentiated precursor cells seem to exhibit phenotypic characteristics which are more fibroblastic than osteoblastic. The view of the bone growth and healing process may be seen on one level as 
undifferentiated cells moving to areas where bone formation is to occur, which then become less mobile and more differentiated until finally the cells become stationary as mature osteoblasts. These cells then begin secreting a bony matrix, which comprises the greater part of mature bone, and become immobilized in this matrix as osteocytes.

The results of the adhesion assay failed to demonstrate any increase in numbers of TGF- $\beta_{1}$ treated MCЗT3.E1 cells attaching to any of the substrates tested compared to control cells. Fibronectin, vitronectin, and type I collagen were selected for use in this assay, since they are all proteins found in the extracellular matrix. Peptite 2000 is a synthetic peptide designed for cell adhesion and one which also contains a receptor for laminin. Albumin was used as a control since the protein is not involved in cellular adhesion. However, it was interesting to note that both groups of cells exhibited substrate concentration dependent attachment to fibronectin, vitronectin, and Peptite 2000, while attachment to type I collagen, the major constituent of the extracellular matrix in bone, was not different from background levels.

Although the cell growth assay demonstrates an increase in the rate of cell proliferation among MC3T3.E1 cells treated with TGF- $\beta_{1}$ compared to control cells after day three, this does not rule out the possibility of localized differences in cell proliferation within the culture dish. The results of the ${ }^{3} \mathrm{H}$-thymidine incorporation 
assay, however, demonstrate that the differences in growth front migration between TGF- $\beta$, treated and untreated MC3T3.E1 cells cannot be explained by different rates of cell proliferation in this particular area. Following 72 hour incubation time with TGF- $\beta_{1}$, cell growth is increased compared to untreated cells (Fig. 3). However, at the same time point similar rates of proliferation are observed at the streak border for both groups of cells. This result correlates with the findings of Zuk and Wezeman ${ }^{(52)}$ who found that proliferation contributed only negligibly to the migration of osteoblast-like cells on coated culture dishes.

Potential Mechanisms of Action of TGF- $\beta_{1}$, on the Motility of Osteoblast-like Cells

The apparent effect of TGF- $\beta_{1}$ in reducing the motility of MC3T3.E1 cells is a finding which may have importance in understanding the factors which regulate bone growth and development. Several mechanisms of the action of TGF- $\beta_{1}$ can be proposed to explain this effect on osteoblast-like cell motility. First, the growth factor may exert its effect by causing changes in the cytoskeletal organization of the cell which could effect its ability to spread. Based on observations that TGF- $\beta$, causes morphological changes in MC3T3.E1 cells from a cuboidal to an elongated spindle shape, ${ }^{(4)}$ it seemed likely that the cytoskeleton of the cell would likewise be effected. However, our initial experiments using a phalloidin stain procedure failed to demonstrate differences in the cytoskelton between TGF- $\beta_{1}$, treated and control MC3T3.E1 cells. Further investigations in this area may be considered, though, 
perhaps by varying the concentration and length of treatment with TGF- $\beta_{1}$.

A second potential mechanism of action of TGF- $\beta_{1}$ in regulating osteoblast-like cell motility is that the growth factor may trigger an increase in integrin expression or receptors for the various ECM proteins, thus resulting in increased adherence, and decreased motility, of the cells to substrate. While several investigators have shown that TGF- $\beta_{1}$ regulates the expression of specific integrins for epithelial and fibroblastic cells, ${ }^{(53,54,55)}$ the results of the adhesion assay do not support this mechanism of motility regulation since pre-treatment with TGF- $\beta_{1}$ did not result in increased attachment of MC3T3.E1 cells to the various ECM proteins used as substrate. One possible explanation for this result may be that the cells require a longer period of preincubation with TGF- $\beta_{1}$ in order for increased integrin expression to occur. However, repeating our adhesion assay with cells incubated with TGF- $\beta_{1}$ for 72 hours did not produce results which differed from the findings reported here using a 24 hour incubation period (data not shown). Also, TGF- $\beta_{1}$ may not influence integrin expression in osteoblast-like cells to the extent it does in other cell types, as has been mentioned previously.

Third, TGF- $\beta_{1}$ may regulate the production of ECM products, which in turn could again effect adherence, thus affecting the ability of the cells to move. Previous investigators have demonstrated that TGF- $\beta_{1}$ stimulates matrix production by bone cells, and by differential effects on individual matrix components, including collagen 
and fibronectin, TGF- $\beta_{-}$, may also influence the nature of the matrix formed by different bone cell populations. ${ }^{(18,19,56)}$ TGF- $\beta_{1}$, then may regulate osteoblast-like cell motility by increasing production of products which form a substrate on which the cells attach. However, this same mechanism could also arguably propose a role for TGF- $\beta_{1}$ in increasing cell motility by stimulating the production of substrate and giving the cells an increased area to attach and spread. 


\section{SUMMARY AND CONCLUSIONS}

This investigation demonstrated a clear inhbition of MC3T3.E1 cell motility by treatment with TGF- $\beta_{1}$, and showed that the underlying mechanism of this inhibition does not appear to be related to cell proliferation. Given that the exact role of TGF$B_{1}$ in reducing motility in osteoblast-like cells remains undefined, it seems likely that several mechanisms or levels of regulation are involved, interactions with other factors are present, and that the process is undoubtedly quite complex.

The conclusions from this investigation can be stated as follows.

1. Osteoblast-like ROS $17 / 2.8$ and SAOS-2 cells have significantly lower motility rates compared to fibroblast-like EL2 and HT cells.

2. TGF- $\beta$, substantially decreases cell motility in osteoblast-like MC3T3.E1 cells, whereas its effect on the growth of the cells is delayed.

3. Increased cell proliferation at the streak border may contribute to the movement of cells into the cell free area but does not explain the reduction in MC3T3.E1 motility caused by TGF- $\beta_{1}$.

4. MC3T3.E1 cells attached efficiently to fibronectin, vitronectin, and the synthetic peptite 2000 but failed to attach to type I collagen and albumin. 
5. Treatment with TGF- $\beta_{1}$ does not significantly effect the attachment of MC3T3.E1 cells to the ECM proteins evaluated in this study.

6. Staining of f-actin filaments using fluorescein phalloidin failed to demonstrate quantifiable quantifiable differences in cytoskeletal organization between treated and control MC3T3.E1 cells. 
TABLE 1

${ }^{3} \mathrm{H}$ Thymidine incorporation in MC3T3.E1 cells

${ }^{3} \mathrm{H}$-Thymidine incorporation in TGF- $\beta$, treated $(2 \mathrm{ng} / \mathrm{ml})$ and control MC3T3.E1 wounded cell cultures. Numbers represent \% of labeled cells \pm S.D. of eight determinations.

TIME OF ${ }^{3} \mathrm{H}$ THYMIDINE INCORPORATION INTO WELL
PERCENT OF LABELED CELLS

AT STREAK BORDER

\section{DAY 0}

WITH TGF- $\beta_{1}$

WITHOUT TGF- $\beta_{1}$

DAY 3

WITH TGF- $\beta_{1}$

WITHOUT TGF- $\beta_{1}$

* $\mathrm{p} \leq 0.01$

$\star \star$ N.S.
$38.0 \pm 7.0^{*}$

$25.0 \pm 5.0$

$73.0 \pm 9.0$ *

$70.0 \pm 9.0$ 


\section{Figure 1: Wound healing assay using MC3T3.E1 Cells}

Arrows mark the original position of the streak border defined as a $1.0 \mathrm{~mm}$ section of the streak border where approximately 10 cells are found on the cell free side of the streak. Bar equals $1.0 \mathrm{~mm}$. a- control well at time of wounding, $\mathbf{b}$ - control well 11 days following placement of the wound, $C$ - well treated with TGF- $\beta_{1}(2 \mathrm{ng} / \mathrm{ml})$ at time of wounding, $\mathbf{d}$ - treated well 11 days following placement of wound. 
CONTROL
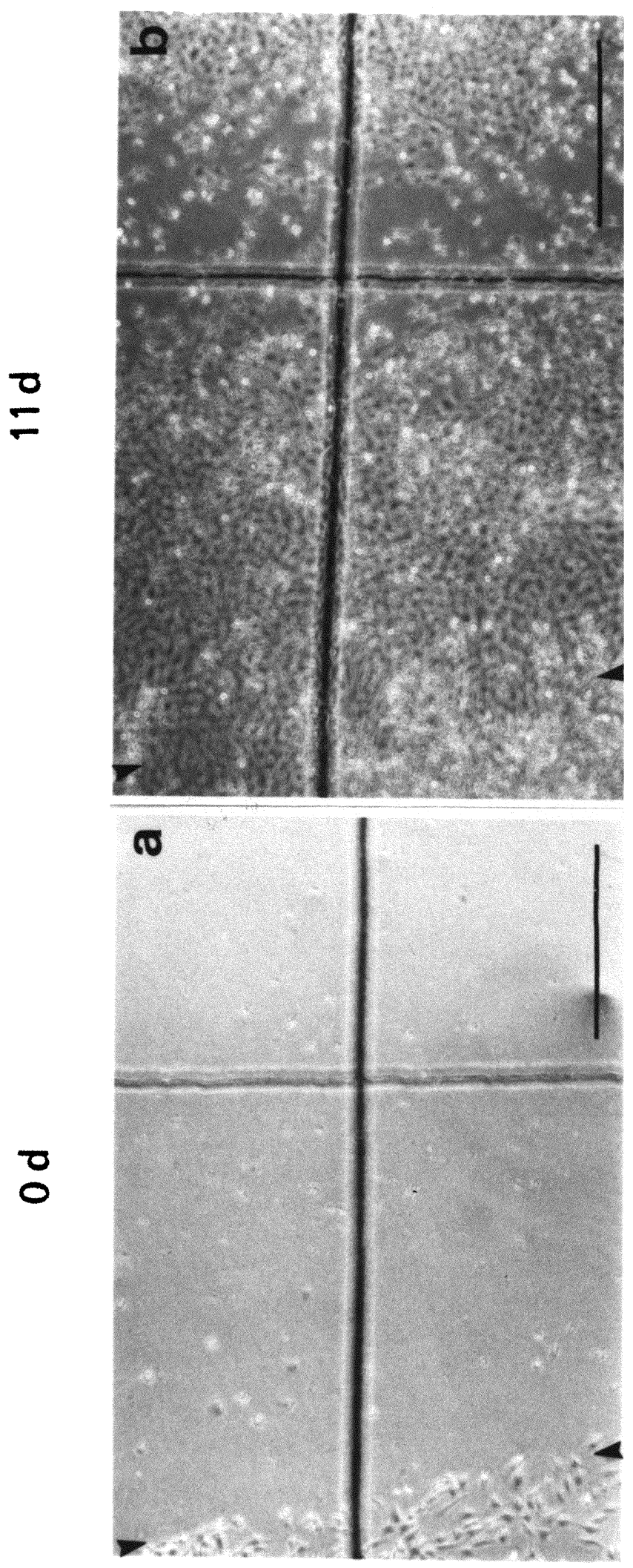

\section{TGF- $\beta_{1}$}
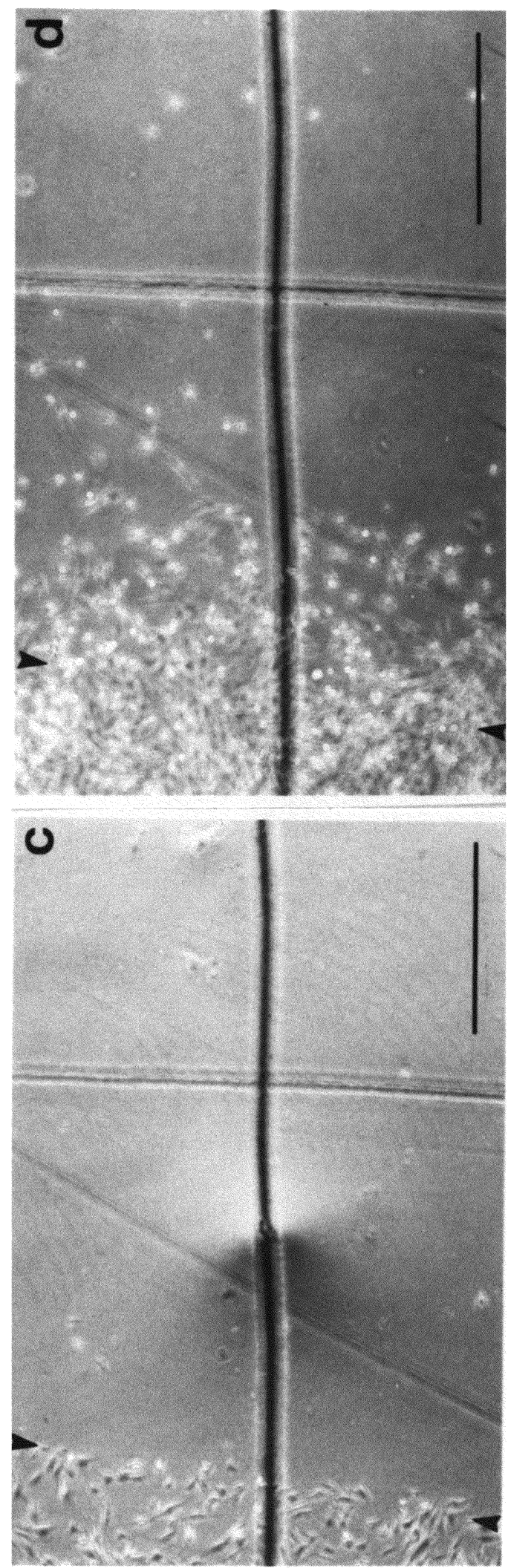
Figure 2: Reduction of MC3T3.E1 cell motility by TGF- $\beta_{1}$.

Growth front migration of MC3T3.E1 cells treated with TGF- $\beta_{1}$ (black diamonds) and untreated MC3T3.E1 cells (open squares) from the wound healing assay. Each value is the mean \pm STD of a minimum of six determinations. 


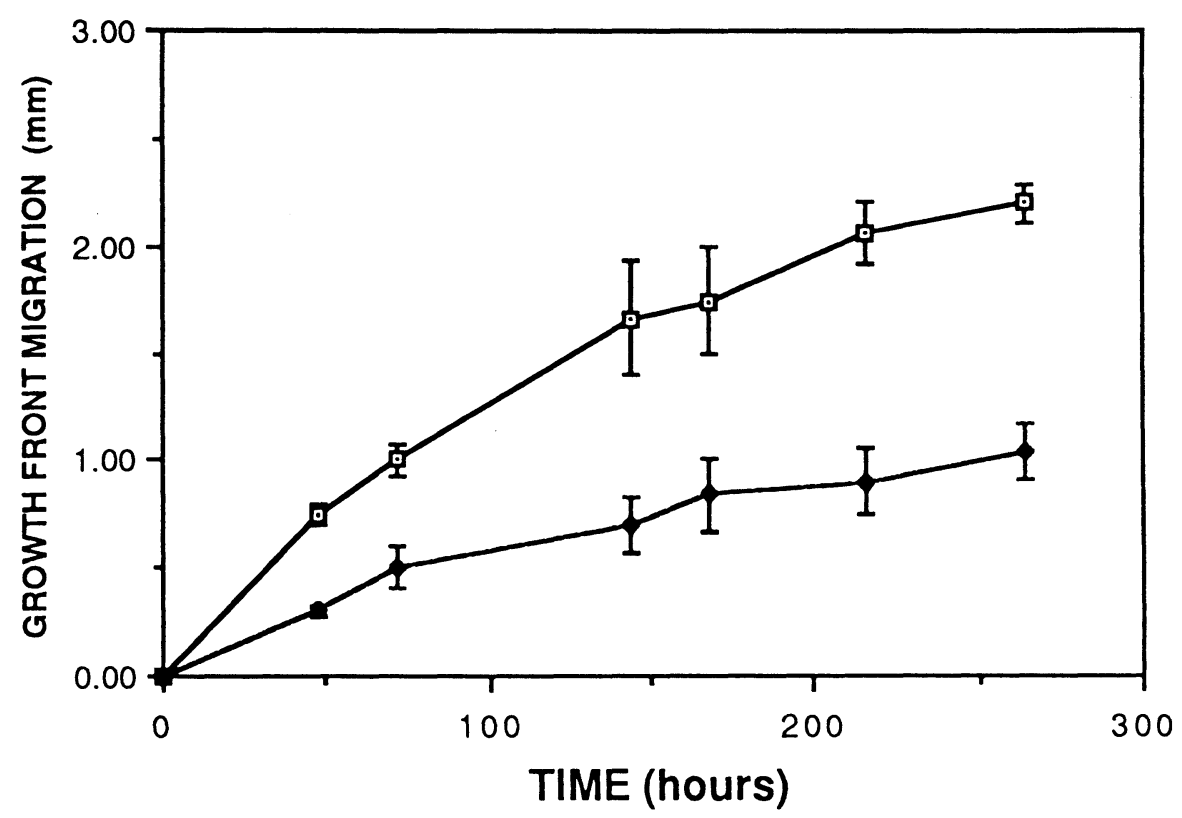


Figure 3: Growth effects of TGF- $\beta$, on MC3T3.E1 cells.

Cell numbers of MC3T3.E1 cells treated with TGF- $\beta_{1}$ (black diamonds) and untreated MC3T3.E1 cells (open squares). Each value is the mean \pm STD of six determinations. 


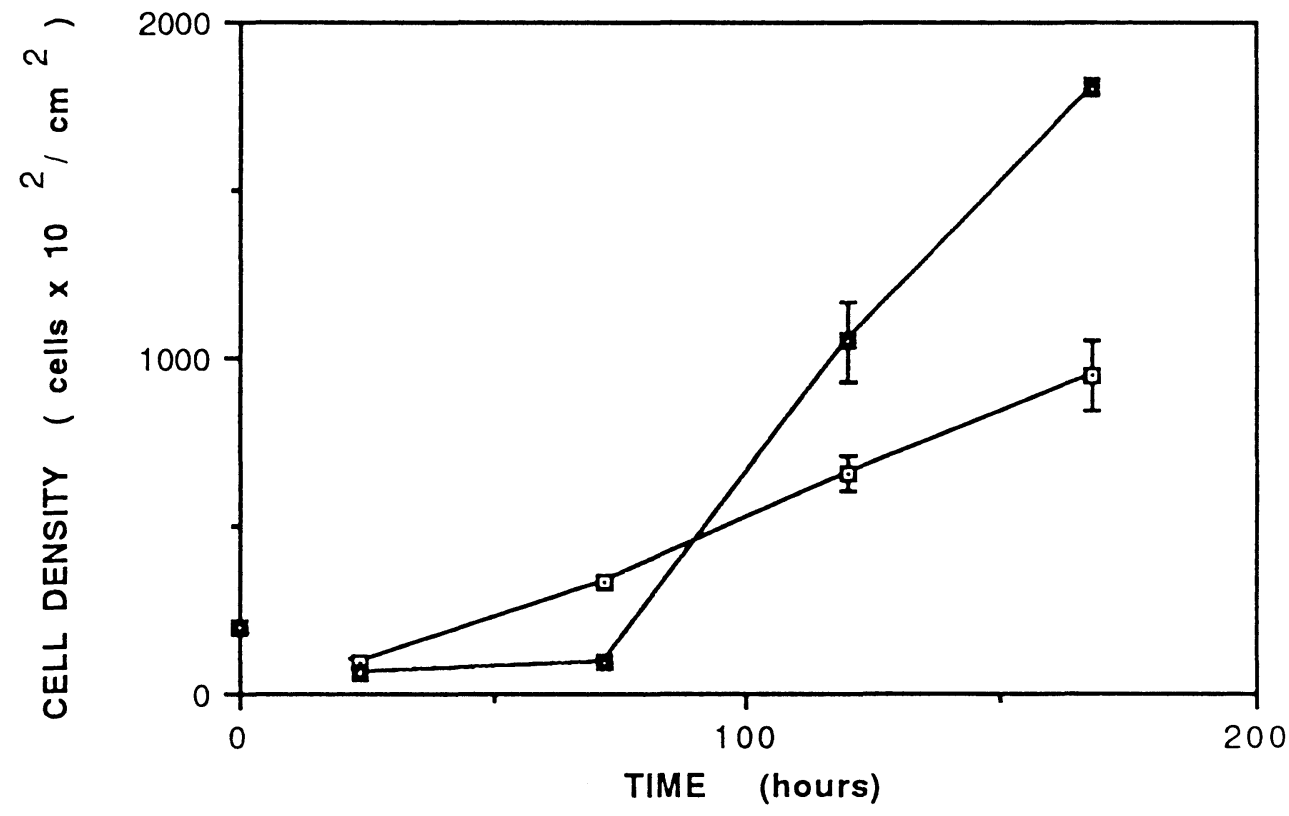


Figure 4: Motility of rat osteoblast-like and fibroblast-like cells.

Cell motility of ROS 17/2.8 (black diamonds) and EL2 (open squares) cells indicating the distance $(\mathrm{mm})$ that the migrating cell growth front moved from the border of the area cleared of cells at the onset of the experiment. Each value is the mean \pm STD of six determinations. 


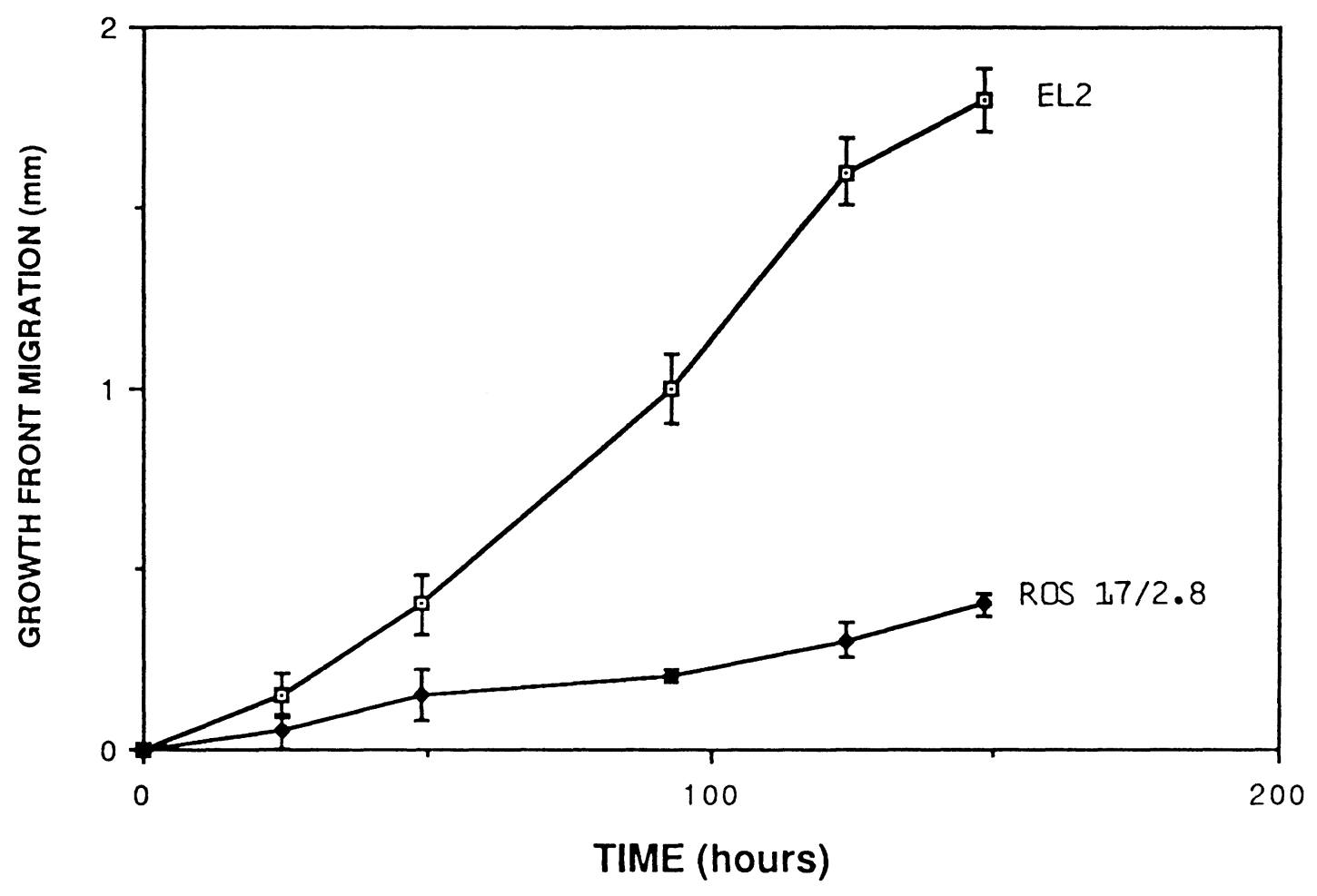


Figure 5: Growth of rat osteoblast-like and fibroblast-like cells.

Growth curves of ROS 17/2.8 osteoblast-like cells (black diamonds) and EL2 fibroblast-like cells (open squares) demonstrating similar initial growth characteristics. Each value is the mean \pm STD of six determinations. 


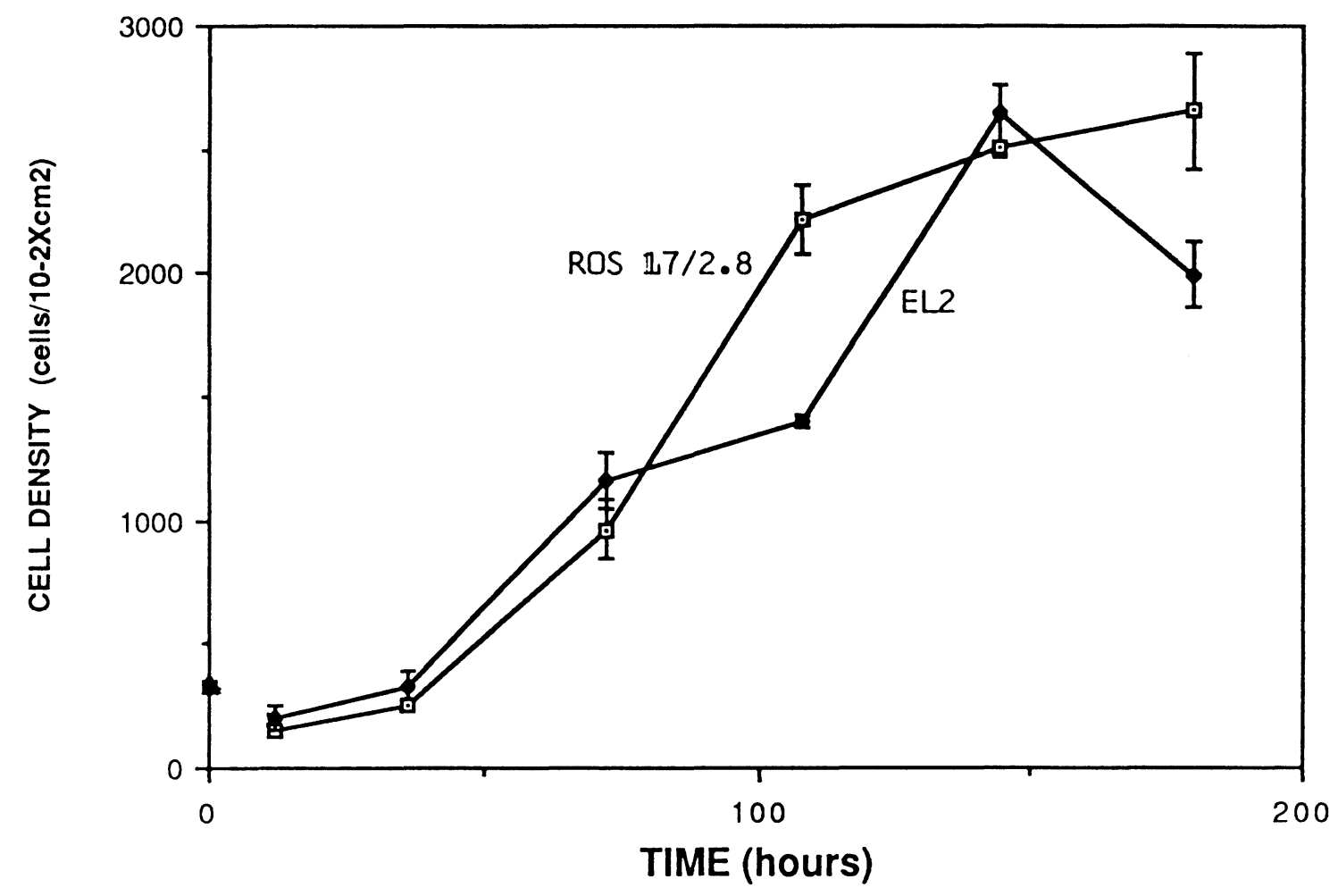


Figure 6: Motility of human osteoblast-like and fibroblast-like cells.

Cell motility of HT human fibroblast cells (black diamonds) and SAOS.2 human osteosarcoma cells (open squares) indicating the distance $(\mathrm{mm})$ that the migtrating cell growth front moved from the border of the area cleared of cells at the onset of the experiment. Each value is the mean \pm STD of eight determinations. 


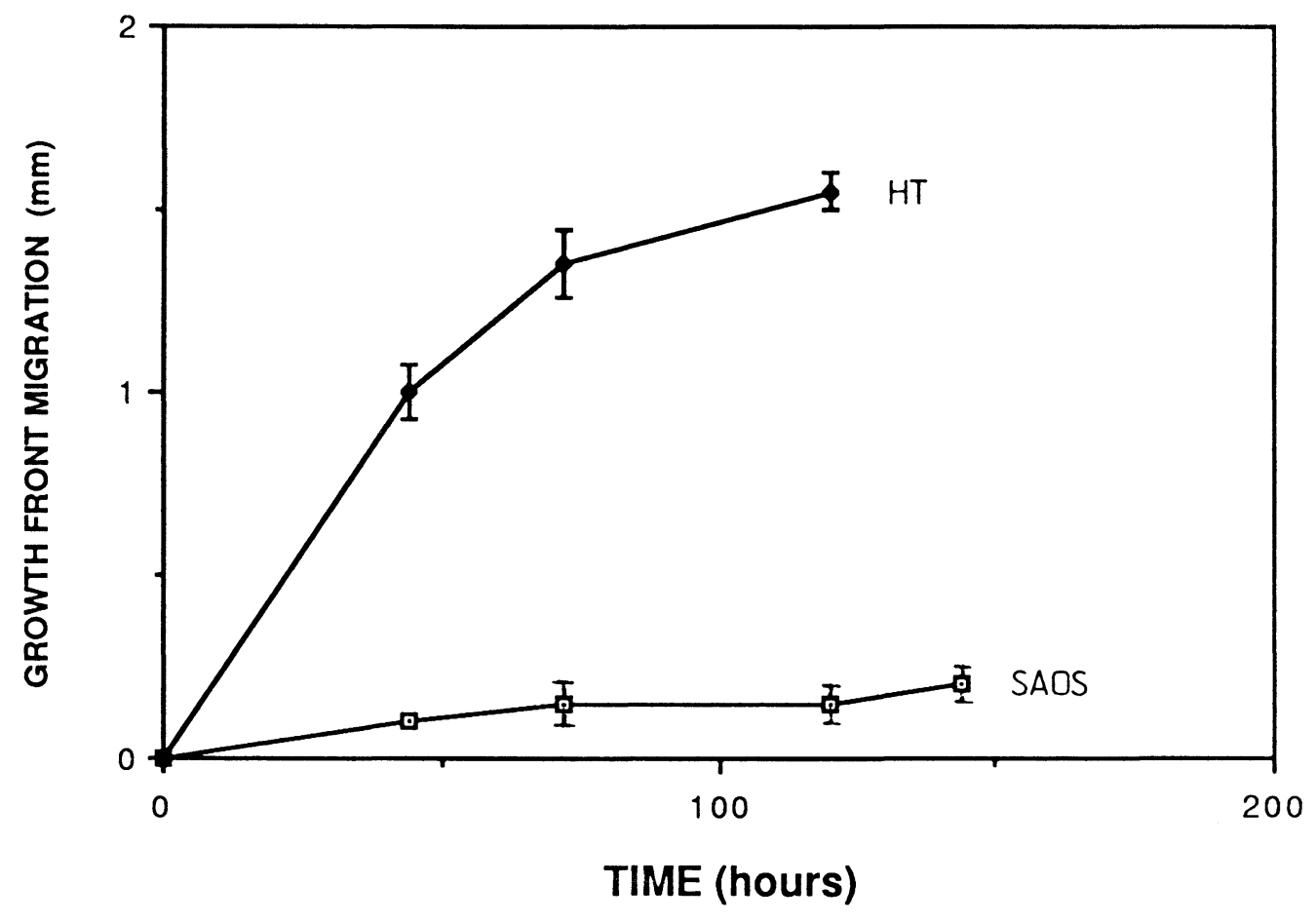


Figure 7: Substrate adhesion of MC3T3.E1 cells.

Cell adhesion assays comparing numbers of TGF- $\beta_{1}$ treated (black diamonds) and control (open squares) MC3T3.E1 cells adhering to $0.1 \mathrm{~mm}^{2}$ area of varying concentrations of peptite 2000, fibronectin, vitronectin, Type I collagen, and albumin. Cells were incubated for 90 minutes. Each value is the mean \pm SEM of a minimum of eight determinations. 

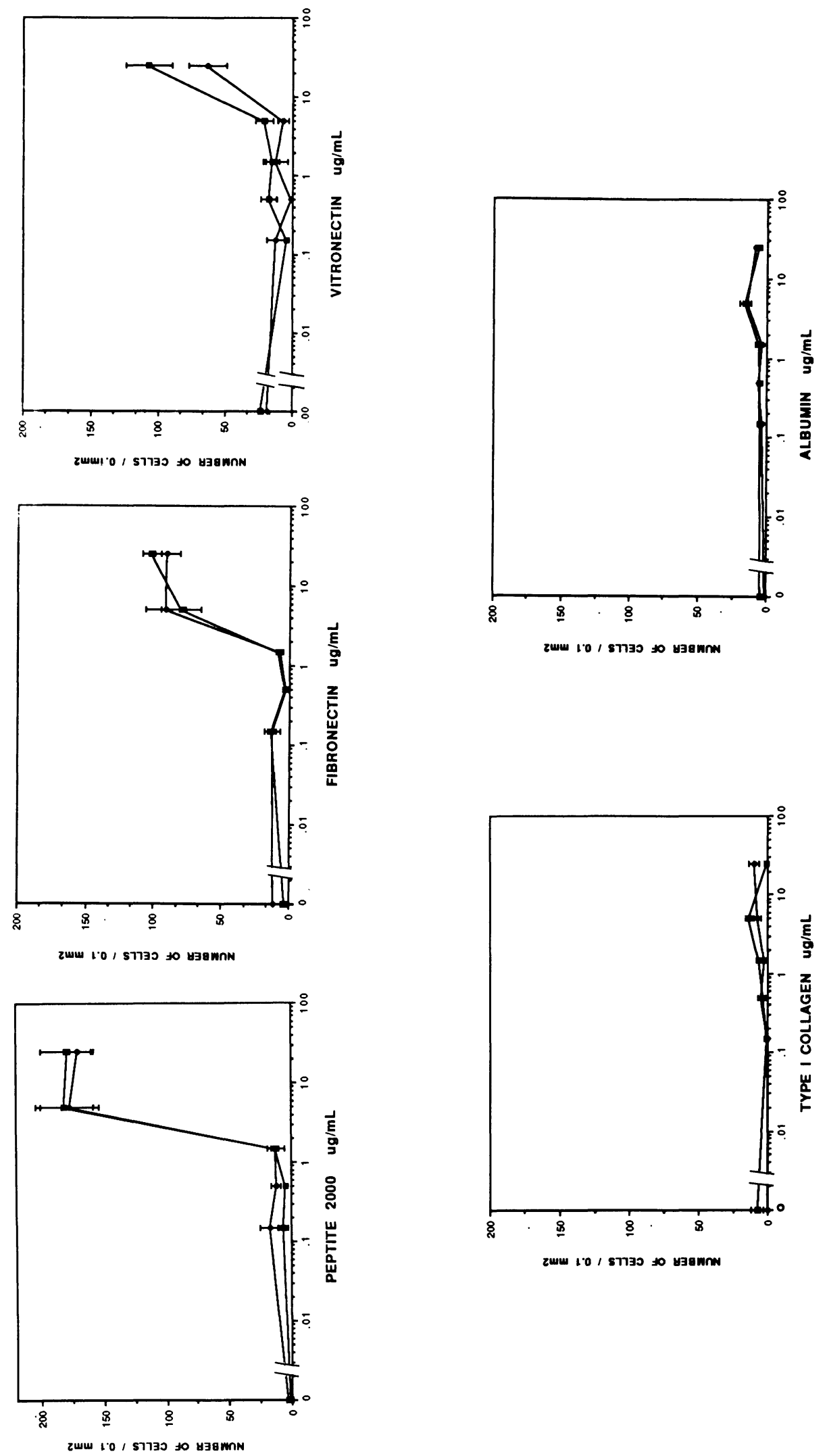
Figure 8: F-Actin staining of MC3T3.E1 cells using fluorescein phalloidin.

MC3T3.E1 cells treated with TGF- $\beta_{1}(2 \mathrm{ng} / \mathrm{ml})$ for 72 hours and control cells were stained for $\mathbf{2 0}$ minutes with a $5 \%$ solution of fluorescein phalloidin. Fluoroscopic examination failed to demonstrate quantifiable differences between control cells-a and treated cells-b. 

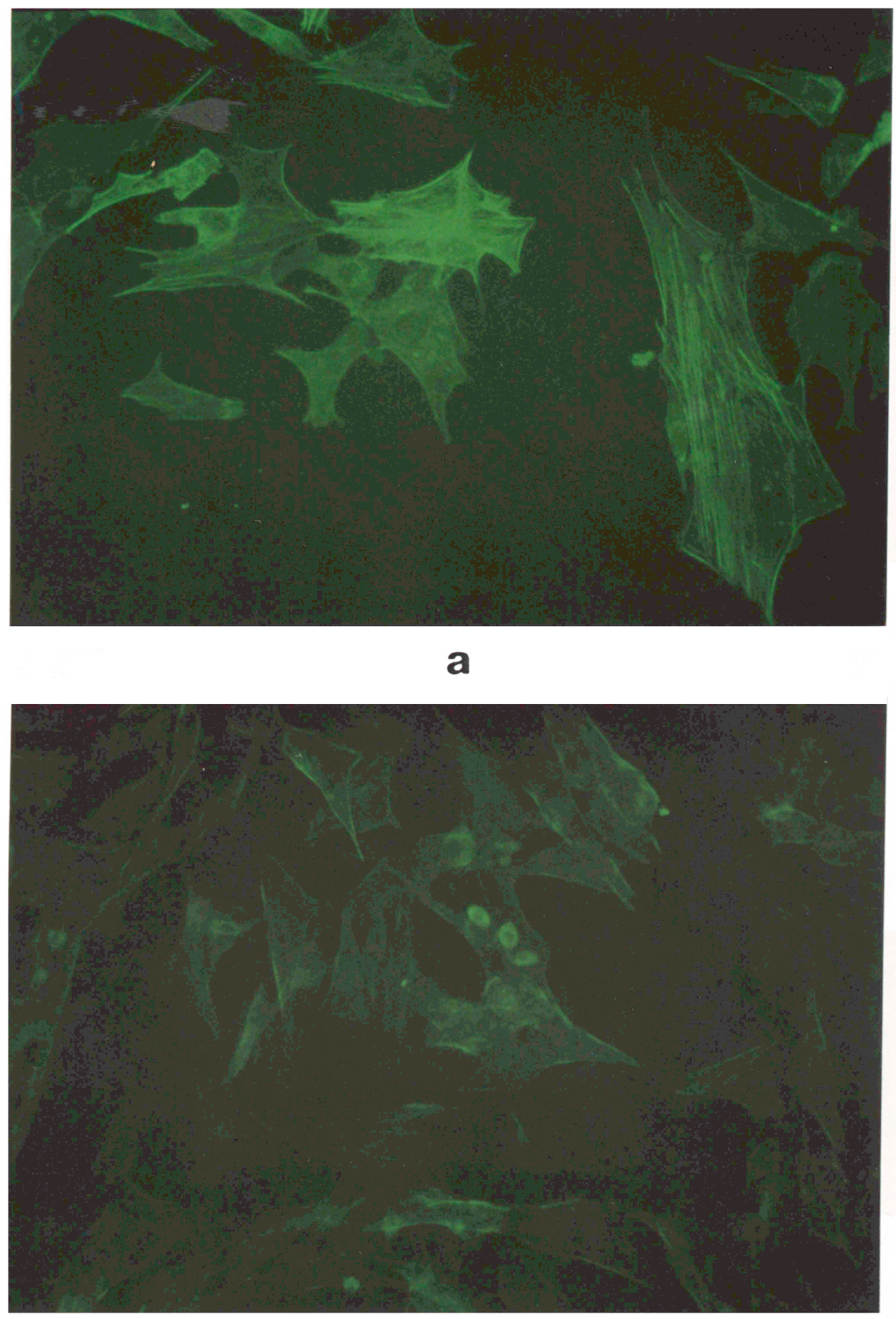

b 
Figure 9: Morphology of control and treated MC3T3.E1 cells.

Confluent cultures of MC3T3.E1 cells treated 8 days with and without TGF- $\beta_{1}$ $(2 \mathrm{ng} / \mathrm{ml})$. Note more cuboidal, osteoblast-like appearance of control cells-a and somewhat spindle shaped appearance of treated cells-b. 


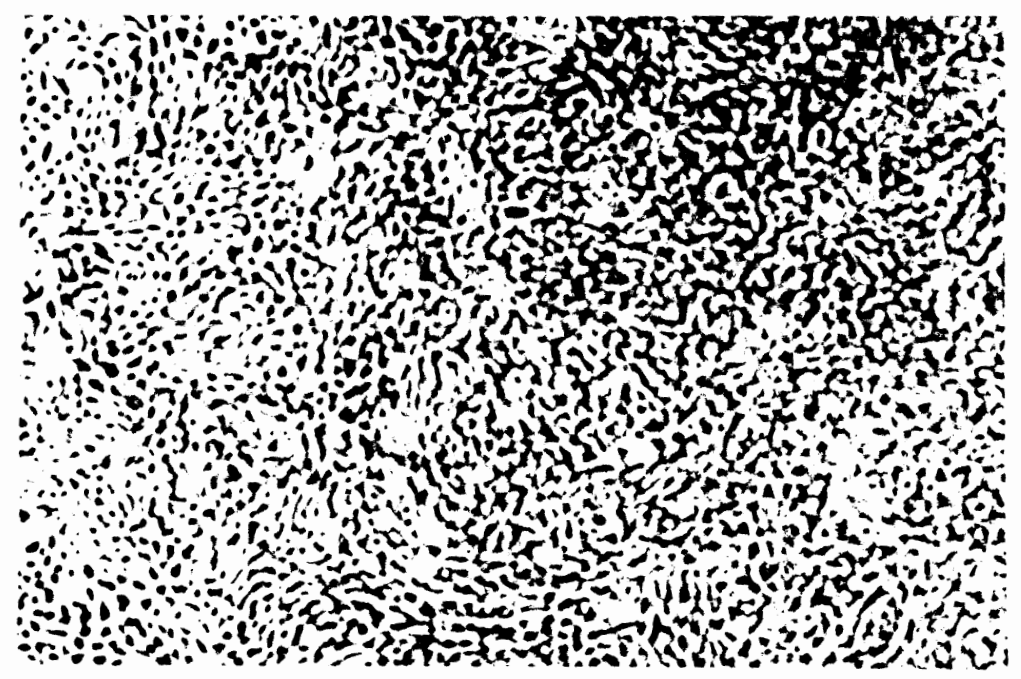

a

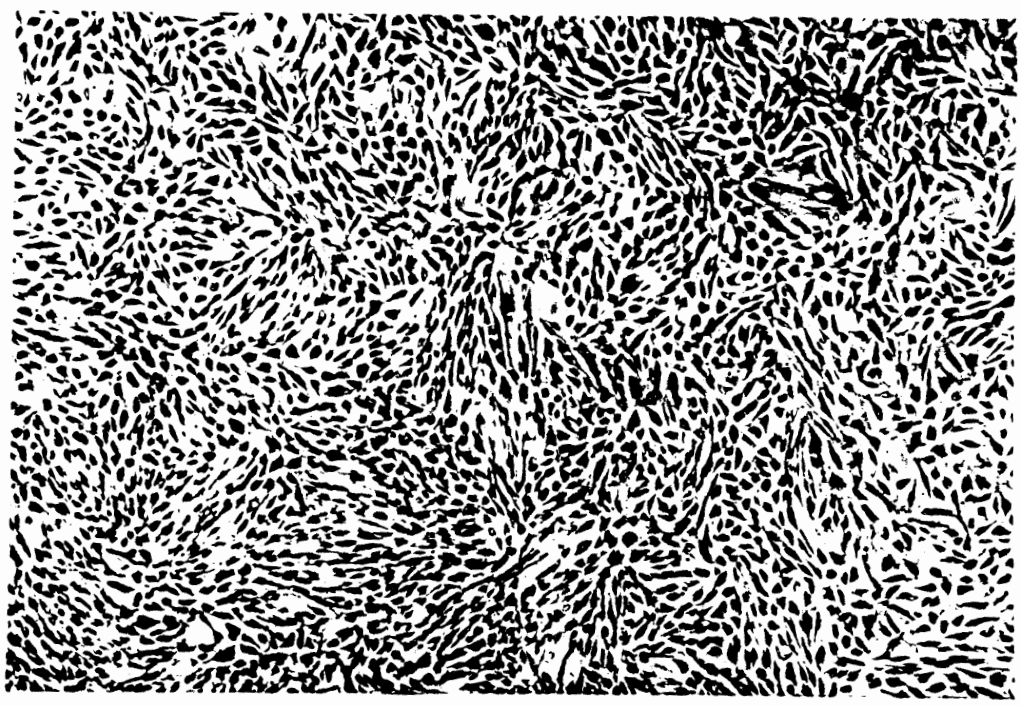




\section{REFERENCES}

1. Bonewald, L.F. and Mundy, G.R. (1989). Role of transforming growth factor-beta in bone remodeling: a review. Connect. Tiss. Res. 23,201-208.

2. Sporn, M.B. and Roberts, A.B. (1990). The Transforming growth factor-betas: past, present, and future. Ann. N. Y. Acad. Sci. 593,1-6.

3. Roberts, A.B., Flanders, K.C., Heine, U.I., Jakowlew, S., Kondaiah, P., Kim, S.-J., and Sporn, M.B. (1990). Transforming growth factor-B: multifunctional regulator of differentiation and development. Phil. Trans. R. Soc. Lond. 327,145154.

4. Noda, M. and Rodan, G.A. (1986). Type-beta transforming growth factor inhibits proliferation and expression of alkaline phosphatase in murine osteoblast-like cells. Biochem. Biophys. Res. Commun. 140,56-65.

5. Rosen, D.M., Stempien, S.A., Thompson, A.Y., and Seyedin, S.M. (1988). Transforming growth factor-beta modulates the expression of osteoblast and chondroblast phenotypes in vitro. J. Cell. Phys. 134, 337-346.

6. Uneno, S., Yamamoto, I., Yamamuro, T., Okumura, H., Ohta, S., Lee,K., Kasai, R., and Konishi, J. (1989): Transforming growth factor beta modulates proliferation of osteoblastic cells: relation to its effect on receptor levels for epidermal growth factor. J. Bone Miner. Res. 4:166-171.

7. Rizzino, A. (1988). Review: transforming growth factor- $\beta$ : multiple effects on cell differentiation and extracellular matrices. Dev. Biol. 130,411-422.

8. Lyons, R.M. and Moses,H.L. (1990). Review: transforming growth factors and the regulation of cell proliferation. Eur. J. Biochem. 187,467-473.

9. Elford, P.R., Guenther, H.L., Felix, R., Cecchini, M.G., and Fleisch, H. (1987). Transforming growth factor $-B$ reduces the phenotypic expression of osteoblastic MC3T3-E1 cells in monolayer culture. Bone 8,259-262.

10. Kansaki, T., Olofsson, A., Moren, A., Wernstedt, C., Hellman, U., Miyazono, K., Claesson-Welsh, L., and Heldin, C.-H. (1990). TGF-B1 binding protein: a component of the large latent complex of TGF-B1 with multiple repeat sequences. Cell 61,1051-1061.

11. Pfeilschifter, J., Bonewald, L., and Mundy, G.R. (1990). Characterization of the latent transforming growth factor $B$ complex in bone. J. Bone Miner.Res. 5,4958. 
12. Pfeilschifter, J., Wolf, O., Naumann, A., Minne, H.W., Mundy, G.R., and Ziegler, R. (1990). Chemotactic response of osteoblastlike cells to transforming growth factor B. J. Bone Miner. Res. 5,825-830.

13. Ibbotsoon, K.J., Christopher, M.O., Anglin, A., and D'souza, S.M. (1989). Effects of transforming growth factors $B_{1}$ and $B_{2}$ on a mouse clonal, osteoblastlike cell line MC3T3-E1. J. Bone Miner. Res. 4, 37-45.

14. Roberts, A.B., and Sporn, M.B. (1989). Regulation of endothelial cell growth, architecture, and matrix synthesis by TGF- $\beta_{1}$. Am. Rev. Respir. Dis. 140,11261128.

15. Seyedin, S.M., Thompson, A.Y., Bentz, H., Rosen, D.M., McPherson, J.M., Conti, A., Seige, N.R., Galuppi, G.R., and Piez, K.A. (1986). Cartilage inducing factorA: Apparent identity to transforming growth factor-beta. J. Biol. Chem. 261,56935695.

16. Centrella, M., McCarthy, T.L., and Canalis, E. (1987). Transforming growth factor $B$ is a bifunctional regulator of replication and collagen synthesis in osteoblastenriched cell cultures from fetal rat bone. J. Biol. Chem. 262,2869-2874.

17. Vukicevic, S., Luyten, F.P., and Reddi, A.H. (1990). Osteogenin inhibits proliferation and stimulates differentiation in mouse osteoblast-like cells (MC3T3-E1). Biochem. Biophys. Res. Commun. 166,750-756.

18. Noda, M., and Rodan, G.A. (1989). Type $B$ transforming growth factor regulates expression of genes encoding bone matrix proteins. Conn. Tiss. Res. 21,71-75.

19. Wrana, J.L., Maeno, M., Hawrylyshyn, B., Yao, K.-L., Domenicucci, C., and Sodek, J. (1988). Differential effects of transforming growth factor-beta on the synthesis of extracellular matrix proteins by normal fetal rat calvarial bone cell populations. J. Cell Biol. 106,915-924.

20. Joyce, M.E., Jingushi, S., Bolander, M.E. (1990). Transforming growth factor- $\beta$ in the regulation of fracture repair. Ortho. Clin. Nor. Amer. 21,199-209.

21. Grobstein, G. (1967). Mechanisms of organogenetic tissue interaction. Nat. Cancer Inst. Mono. 26,279-299.

22. Rodan, G.A., and Rodan, S.B. (1983). Expression of the osteoblastic phenotype. In: Peck, W.A. (ed.) Bone and Mineral Research, Annual 2. Elsevier Science Publishers, Amsterdam, pp. 244-285

23. Ten Cate, (1985). Oral Histology: Development, Structure, and Function. C.V. Mosby Co., St. Louis, p.p. 109-128. 
24. Wright, G.M. and Leblond, C.P. (1981). Immunohistochemical localization of procollagens. III. Type I procollagen antigenicity in osteoblasts and prebone (osteoid). J. Histochem. Cytochem. 29,791-804.

25. Price,P. (1983). Non-collagen proteins of hard tissue. In: Peck, W.A. (ed.) Bone and Mineral Research, Annual 1. Excerpta Medica, Amsterdam, pp. 157-191.

26. Rao, L.G., Ng, B., Brunette, M., and Heersche, J.N.M. (1977). Parathyroid hormone-and prostaglandin E1-response in a selected population of bone cells after repeated subculture and storage at -80C. Endocrinology 100,1233-1241.

27. Chen, T.L., Aronow, L., and Feldman, D. (1977). Glucocorticoid receptors and inhibition of bone cell growth in primary cultures. Endocrinology 100,619-628.

28. Sudo, H., Kodama, H.-A., Amagai, Y., Yamamoto, S., and Kasai, S. (1983). !n vitro differentiation and calcification in a new clonal osteogenic cell line derived from newborn mouse calvaria. J. Cell Biol. 96,191-198.

29. Fogh, J., and Trempe, (1975): In: J. Fogh (ed.) Human tumor cell lines in vitro. Plenum Press, New York, p.p. 115-159.

30. Majeska, R.J., Rodan, S.B., and Rodan, G.A. (1980). Parathyroid hormone responsive clonal cell lines from rat osteosarcoma. Endocrinology 107,14941503.

31. Aubin, J.E., Heersche, J.N.M., Jerrilees, M.J., and Sodek, J. (1982). Isolation of bone cell clones with differences in growth, hormone responses, and extracellular matrix production. J. Cell. Biol. 92,452-461.

32. Howard, G.A., Bottemiller, B.L., Turner, R.T., Rader, J.I, and Baylink, D.J. (1981). Parathyroid hormone stimulates bone formation and resorption in organ culture: Evidence for a coupling mechanism. Proc. Natl. Acad. Sci. USA 78,3204-3208.

33. Deuel, T.F., (1987). Polypeptide growth factors: roles in normal and abnormal cell growth. Ann. Rev. Cell Biol. 3,443-492.

34. Poser, J. (1985): Calcif. Tiss. Int. 38, Suppl. S21.

35. Centrella, M., McCarthy, T.L., and Canalis, E. (1988). Skeletal tissue and transforming growth factor beta. FASEB J. 2,3066-3073.

36. Le Douarin, N.M., (1984). Cell migrations in embryos. Cell 38,353-360.

37. Toole, B.P., Jackson, G., and Gross, J. (1972). Hyaluronate in morphogenesis: inhibition of chondrogenesis in vitro. Proc. Nat. Acad. Sci. USA 69,1384-1386. 
38. Weston, et al., (1978): Changes in the extracellular environment of neural crest cells during their early migration. Zoon, 6:103-113.

39. Hynes, R.O. and Yamada, K.M.(1982). Fibronectins: multifunctional modular glycoproteins. J. Cell Biol. 95,369-377.

40. Yamada, K.M. (1983). Cell surface interactions with extracellular materials. Ann. Rev. Biochem. 52,761-799.

41. Rovasio, R.A., Delouvee, A., Yamada, K.M., Timpl, R., and Thiery, J.P. (1983). Neural crest cell migration: requirements for exogenous fibronectin and high cell density. J. Cell Biol. 96,462-473.

42. Pierschbacher, M., and Ruoslahti, E. (1984). Variants of the cell recognition site of fibronectin that retain attachment-promoting activity. Proc. Natl. Acad. Sci. USA 81,5985-5988.

43. Ruoslahti, E., Hayman, E.G., Pierschbacher, M., and Engvall, E., (1982). Fibronectin: purification, immunochemical properties, and biological activities. Meth. in Enzym. 82,803-831.

44. Ruoslahti, E., and Pierschbacher, M. (1987). New Perspectives in Cell Adhesion: RGD and Integrins. Science 238,491-497.

45. Liboi, E., Caruso, M., and Basilico, C. (1984): New rat cell line that is highly susceptible to transformation by several oncogenes. Mol. Cell. Biol. 4,2925-2928.

46. Rasheed, S.J., Nelson-Rees, W.A., Toth, E.M., Arnstein, P., and Gardner, M.B. (1974). Cancer, 33:1027-1033.

47. Lackie, J.M. (1986). Cell movement and cell behaviour. Allen \& Unwin Publishers Ltd, London. pp. 155-172.

48. Ecarot-charrier, B., Glorieux, F.H., Van Der Rest, M. and Pereira, G. (1983). Osteoblasts isolated from mouse calvaria initiate matrix mineralization in culture. J. Cell Biol. 96,639-643.

49. Davies, J.E., Causton, B., Bovell, Y., Davy, K., and Sturt, C.S. (1986). The migration of osteoblasts over substrata of discrete surface charge. Biomaterials 7,231-233. 
50. Adelmann-Grill, B.C., Wach, F., Cully, Z., Hein, R., and Krieg, T. (1990). Chemotactic migration of normal dermal fibroblasts towards epidermal growth factor and its modulation by platelet-derived growth factor and transforming growth factor-beta. Euro. J. Cell Biol. 51, 322-326.

51. Muller, G., Behrens, J., Nussbaumer, U., Bohlen, P., and Birchmeier, W. (1987): Inhibitory action of transforming growth factor $B$ on endothelial cells. Proc. Natl. Acad. Sci. USA 84,5600-5604.

52. Zuk, A., and Wezeman,F.H. (1986). Concomitant analysis of osteoblastlike cell migration and proliferation on a serum-enriched growth surface. Anat. Rec. 214, 96-102.

53. Ignotz, R.A., Heino, J., Massague, J. (1989). Regulation of cell adhesion receptors by transforming growth factor- $B$ : regulation of vitronectin receptor and LFA-1. J. Biol. Chem. 264,389-392.

54. Heino, J., Ignotz, R.A., Hemler, M.E., Crouse, C., Massague, J., (1989). Regulation of cell adhesion receptors by transforming growth factor- $B$ : Concomitant regulation of integrins that share a common $\beta_{1}$ subunit. J. Biol. Chem. 264,380-389.

55. Ignotz, R.A. and Massague, J. (1987): Cell adhesion protein receptors as targets for transforming growth factor- $B$ action. Cell, 51:189-197.

56. Roberts, A.B., Heine, U.I., Flanders, K.C., and Sporn, M.B. (1989). Transforming growth Factor- $B$ : Major role in regulation of extracellular matrix. Ann. N.Y. Acad. of Sci. 580,225-233.

57. Hynes, R.O. (1987). Integrins: A family of cell surface receptors. Cell 48,549-554.

58. Wiestner, M., Fischer, S., Dessau, W., Muller, P.K. (1981). Collagen types synthesized by isolated calvarium cells. Exp. Cell Res. 133,115-125.

59. Bronner, F. (1991). Bone formation and bone resorption. In: Bronner, F. and Worrell, R.V. (eds.) A Basic Science Primer in orthopaedics. Baltimore: Williams and Wilkins publishers, pp. 81-90.

60. Mundy, G.R. (1989). Identifying mechanisms for increasing bone mass. J. NIH Res. 1,65-68.

61. Rodan, G.A. and Martin, T.J. (1981). Role of osteoblasts in hormonal control of bone resorption - a hypothesis. Calcif. Tiss. Int. 33,349-351. 